\title{
Visual Projections Routed to the Auditory Pathway in Ferrets: Receptive Fields of Visual Neurons in Primary Auditory Cortex
}

\author{
Anna W. Roe, ${ }^{a}$ Sarah L. Pallas, ${ }^{\mathrm{b}}$ Young H. Kwon, and Mriganka Sur \\ Department of Brain and Cognitive Sciences, Massachusetts Institute of Technology, Cambridge, Massachusetts 02139
}

\begin{abstract}
How does cortex that normally processes inputs from one sensory modality respond when provided with input from a different modality? We have addressed such a question with an experimental preparation in which retinal input is routed to the auditory pathway in ferrets. Following neonatal surgical manipulations, a specific population of retinal ganglion cells is induced to innervate the auditory thalamus and provides visual input to cells in auditory cortex (Sur et al., 1988). We have now examined in detail the visual response properties of single cells in primary auditory cortex (A1) of these rewired animals and compared the responses to those in primary visual cortex (V1) of normal animals. Cells in A1 of rewired animals differed from cells in normal $V_{1}$ : they exhibited larger receptive field sizes and poorer visual responsivity, and responded with longer latencies to electrical stimulation of their inputs. However, striking similarities were also found. Like cells in normal V1, A1 cells in rewired animals exhibited orientation and direction selectivity and had simple and complex receptive field organizations. Furthermore, the degree of orientation and directional selectivity as well as the proportions of simple, complex, and nonoriented cells found in $A 1$ and $V 1$ were very similar. These results have significant implications for possible commonalities in intracortical processing circuits between sensory cortices, and for the role of inputs in specifying intracortical circuitry.
\end{abstract}

Is cortex of a given sensory modality uniquely specified to process inputs of that modality, or can it, under certain conditions, process input of another modality? The qucstion is important for understanding intrinsic and extrinsic determinants of cortical development, and for understanding plasticity and recovery of function following early brain trauma. In this article, we have addressed the issue by routing visual inputs into the auditory pathway during development and subsequently studying the resulting visual responses of cells in auditory cortex in the adult. We have previously demonstrated that, following specific neonatal lesions, retinal afferents in the ferret can be induced to innervate the auditory thalamus (specifically, the medial genic-

\footnotetext{
Received Jan. 6, 1992; revised Apr. 14, 1992; accepted Apr. 20, 1992.

We thank Preston Garraghty for participating in early experiments and for critical review of an earlier version of the manuscript, Sacha Nelson for reviewing the manuscript, and Terry Sullivan for excellent technical assistance. This work was supported by a Whitaker Foundation fellowship (A.W.R.), NIH Postdoctoral Fellowship EY 06121 (S.L.P.), NIH Grant EY 07719 (M.S.), and a grant from the McKnight Foundation (M.S.)

a Present address, to which correspondence should be addressed: Annd W. Rue, Laboratory of Neurobiology, Rockefeller University, 1230 York Avenue, New York, NY 10021.

- Present address: Division of Neuroscience, Baylor College of Medicine, 1 Baylor Plaza, Houston, TX 77030
}

Copyright (C) 1992 Society for Neuroscience $0270-6474 / 92 / 123651-14 \$ 05.00 / 0$ ulate nucleus, or MGN). Retinal afferents subsequently provide visual input to cells in primary auditory cortex (A1) of the "rewired" ferret (Sur et al., 1988) and establish a topographic visual map there (Roe et al., 1990a). We have now examined both qualitatively and quantitatively the physiological response properties of single visual units in Al of rewired ferrets and compared them to the properties of cells in primary visual cortex (V1) of normal ferrets.

A preliminary report of these data has been published previously (Roe et al., 1990b).

\section{Materials and Methods \\ Neonatal surgery to route retinal projections to the $M G N$}

To induce retinal innervation of nonvisual thalamic structures, it is necessary to remove the normal retinal targets [primarily the lateral geniculate nucleus (LGN) and the superior colliculus (SC)] and to make alternative target space available [in this case, the medial geniculate nucleus (MCN); see Schneider, 1973].

Procedures were similar to those described previously (Pallas et al., 1990). Briefly, timed pregnant pigmented ferret jills were bred in our colony or purchased from a commercial supplier (Marshall Farms) Within $24 \mathrm{hr}$ of parturition, ferret kits were removed and anesthetized by deep hypothermia. All surgery was performed under sterile conditions. A $1 \mathrm{~cm}$ midline incision was made in the scalp and the skull was exposed. After removing a small piece of overlying skull, the SC was ablated by cautery. To induce massive retrograde degeneration of the LGN, large regions of visual cortex (including areas 17,18, and often 19) were lesioned by cauterizing through the skull. Fibers running in the brachium of the inferior colliculus were transected at the mid-SC level, thereby denervating the MGN. All lesions were made unilaterally (bilateral lesions significantly reduced survival rates). On completion of surgery, the skin was sutured and the kit revived under a heat lamp. A single dose of antibiotic $(0.01 \mathrm{cc}$ amoxycillin, $100 \mathrm{mg} / \mathrm{ml})$ was given subcutaneously, and antibacterial ointment was applied to the wound The kit was then returned to the mother for rearing.

These lesions result in induction of developing retinal afferents into the MGN (Sur et al., 1988). Since the normal thalamocortical connectivity from the MGN to primary auditory cortex (A1) is retained (Pallas et al., 1990), an aberrant visual pathway from the retina to MGN to Al is established (Sur et al., 1988).

\section{Visual physiology in adult ferrets}

Surgical preparation. Normal and rewired adult ferrets were prepared for visual physiology using procedures similar to those described previously (Roe et al., 1989). Animals were anesthetized, paralyzed, and respirated. Following induction of anesthesia with ketamine hydrochloride $(30 \mathrm{mg} / \mathrm{kg}$ ) and xylazine $(2 \mathrm{mg} / \mathrm{kg})$, a cannula (24 gauge) for anesthetic and paralytic delivery was implanted in either the femoral or the jugular vein, and an endotracheotomy was performed. Animals were then placed in a stereotaxic apparatus, paralyzed, and artificially respired (rate, $30-40 / \mathrm{min} ; \mathrm{vol}, 25-30 \mathrm{cc}$ ) with a $70: 30$ mixture of nitrous oxide and oxygen. Ferrets received a constant intravenous infusion of a $5 \%$ dextrose solution containing ketamine hydrochloride $(10 \mathrm{mg} / \mathrm{kg}$ hr) for ancsthesia and gallaminc hydrochloride $(3.6 \mathrm{mg} / \mathrm{hr} / \mathrm{kg})$ for muscular paralysis. End-tidal $\mathrm{CO}_{2}$ was maintained at $4.0 \%$, heart rate was monitored, and body temperature was maintained at $38^{\circ} \mathrm{C}$ with a heating 


\begin{tabular}{lcc}
\hline Table 1. Number of units recorded in V1 and $\mathbf{A l}$ & \\
& V1 & A1 \\
\hline Total & 153 & 495 \\
Electrically driven & $124(95)^{\prime}$ & $485(98)$ \\
Visually driven & $105(69)$ & $194(39)$ \\
Visually and electrically driven & $77(59)^{4}$ & $184(37)$ \\
Receptive field size determined & $101(66)$ & $100(20)$ \\
Ocular dominance determined & $76(50)$ & $110(22)$ \\
Cell class determined & $101(66)$ & $52(11)$ \\
Quantitatively characterized & $38(25)$ & $24(5)$ \\
Driven by auditory stimuli & $0(0)$ & $0(0)$ \\
\hline
\end{tabular}

Percentage of total is shown in parentheses.

"Percentage calculated from a total of 131 cells for which chiasm latencies were assessed. In one experiment, chiasm latencies were not assessed (22 cells).

pad. Supplemental halothane (1\%) was supplied during all surgical procedures. The skull and dura overlying visual cortex in normal animals and auditory cortex in rewired animals were removed. Stimulating electrodes were lowered into the optic chiasm and cemented in place. Drops of atropine sulfate and phenylephrine hydrochloride were applied to the eyes to dilate the pupils. Eyes were fitted with zero-power contact lens and focused on a tangent screen $114 \mathrm{~cm}$ in front of the animal. Optic disks were plotted by reflection onto the tangent screen.

Recording and data collection. In 18 rewired and 13 normal adult ferrets, we used parylene-insulated tungsten microelectrodes (2-3 M $\Omega$ impedances) to record extracellularly from isolated cells in $A 1$ of rewired and $\mathrm{Vl}$ of normal animals. Recording penetrations were made in $\mathrm{Al}$ (located between the anterior and posterior limbs of the ectosylvian sulcus; Kelly et al., 1986) and VI (located in the caudal half of the lateral sulcus; Law et al., 1988) on the basis of sulcal patterns. Penetrations were usually spaced $250-500 \mu \mathrm{m}$ apart. Unit activity was assessed every 50-100 $\mu \mathrm{m}$ in each penetration (1) for response to electrical stimulation of the optic chiasm (1-15 V) and (2) for response to visual stimulation. In two rewired animals and one normal animal, pure tone bursts (ranging from 8 to $20 \mathrm{kHz}$ ) or broad-band auditory stimuli (100 ms square-wave clicks or white noise) were delivered binaurally through earphones. Visually responsive units were plotted and characterized on the tangent screen with a hand-held projection lamp. In addition to receptive field location (as determined by reflection of the optic disk, located at $33^{\circ}$ azimuth and $-3^{\circ}$ elevation; Zahs and Stryker, 1985) and receptive field size (measured as $1^{\circ}$ per $2 \mathrm{~cm}$ on a tangent screen located $114 \mathrm{~cm}$ from the eye), a number of other response characteristics were also examined. These included ocular dominance; orientation, direction, and velocity selectivities; spatial organization of on- and off-responses within the receptive field; presence or absence of summation and end-stopping; and strength of response. When possible, oriented cells were classified as simple or complex (Hubel and Wiesel, 1962). Electrolytic lesions ( 5 $\mu \mathrm{A}$ for $5 \mathrm{sec}$ ) were made in selected penetrations.

The tuning characteristics of a subset of isolated single units were studied quantitatively. For quantitative determination of orientation, dircetion, and velocity tuning preferences, moving bar stimuli, either projected with an optic bench or generated on a Tektronix monitor driven by a PICASSo (Innisfree) stimulus generator, were continuously swept (without interleaving) at each orientation (usually at $30^{\circ}$ intervals) and velocity (from $5 \% \mathrm{sec}$ to $100 \% \mathrm{sec}$ ) over the receptive field; each successive orientation and velocity was presented in a pseudorandom fashion. Spike responses of the cell under study were isolated with a pulse-shape discriminator (Ealing). For each category of stimulus, 15 cycles of response were collected and summed by the UNKELSCOPE program run on an IBM PC286 computer, and poststimulus time (PST) histograms were generated on line. Spike responses were also stored on tape, and PST histograms were analyzed off line. Background activity was collected in the absence of visual stimulation.

Histology. Following the completion of data collection, the animal was killed with an intravenous or intraperitoneal overdosc of pentobarbital $(65 \mathrm{mg} / \mathrm{kg})$ and perfused through the heart with saline followed by fixative ( $1 \%$ paraformaldehyde, $2 \%$ glutaraldehyde) and $10 \%$ and $20 \%$ sucrose solutions. The brain was then removed from the cranium and stored in 30\% sucrose overnight. After brain sulcal patterns (Kelly et al., 1986) were recorded photographically, frozen sections were cut

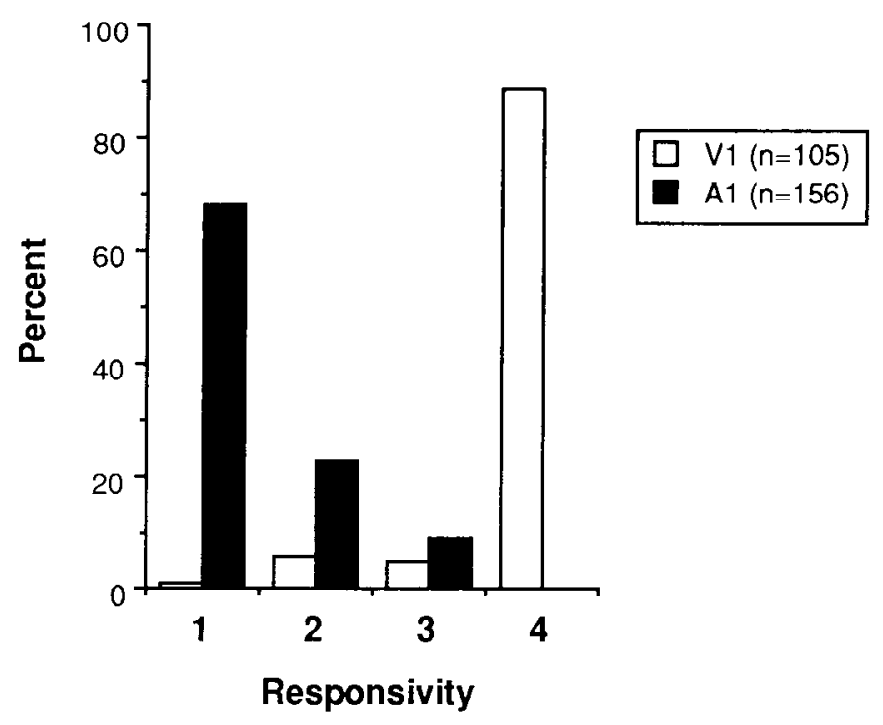

Figure 1. Distribution of responsivities ( $l$ indicates poor responsiveness and 4 good responsiveness) of cells in Al (dark bars) and VI (light bars). These distributions are significantly different $(p<0.0001$, MannWhitney $U$ test). Out of a total of 194 cells, 38 recorded from early experiments in rewired animals were not rated for responsivity.

at $50 \mu \mathrm{m}$ and stained with cresyl violet. Lesions and recording tracks were identified and located with respect to the borders of $\mathrm{Al}$.

Data analysis. For each cell that was studied quantitatively, peak response (maximum spikes/sec summed over at least 10 trials) minus background (average spikes/sec of spontaneous activity summed over identical number of trials) was calculated for every stimulus condition. From these, orientation, velocity, and bar size tuning curves were plotted and selectivity indices calculated. The orientation index was defined as 1 - (orthogonal response/best response), and the direction selectivity index was defined as 1 - (response to direction opposite of preferred direction/response to preferred direction). These are normalized indices, with 1.0 indicating a highly selective and 0 a nonselective cell. In addition, orientation widths were determined at $1 / \sqrt{2}$ height (cf. Schiller et al., 1976b). Unless otherwise specified, statistical tests between two parameters employed at the Mann-Whitney $U$ test. Comparison of groups was done using the $\chi^{2}$ test.

\section{Results}

Four-hundred and ninety-five visual units were recorded from Al of rewired ferrets and 153 visual units from Vl of normal ferrets (see Table 1). Nearly all cells responded to electrical stimulation of the optic chiasm. Of these, $194(39 \%)$ of the cells in $\mathrm{Al}$ and $105(69 \%)$ of the cells in $\mathrm{V} 1$ were visually responsive under our recording conditions. The smaller overall proportion (pooled over all animals studied) of visual cells recorded in Al may be due to poorer responsiveness of Al units (see below) as well as to interanimal variability in lesion size. [In some rewired animals with large visual cortical lesions, almost all units responsive to chiasm stimulation were visually driven, while in animals with small cortical lesions a much lower percentage of visual units was encountered. This variability probably relates to the size of the extant LGN, and hence to the size of the rerouted retinal projection to the MGN (Roe, 1991).] A subset of the visual cells in rewired $A 1$ and normal VI were characterized in further detail and their responses studied quantitatively (Table 1). Of the units that were tested for auditory responsiveness ( $n=35$ in $\mathrm{Al}$ of two rewired ferrets; $n=22$ in $\mathrm{V} 1$ of one normal ferret), none responded either to clicks or to 

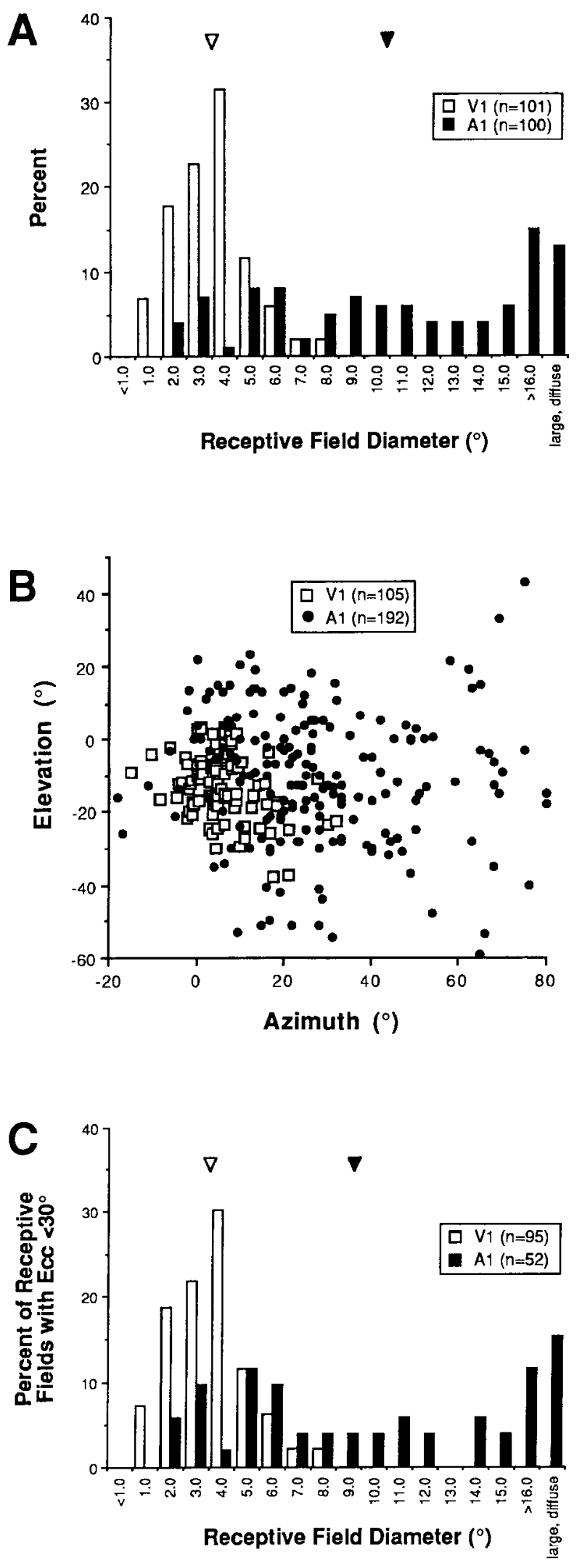

Figure 2. A, Receptive field diameters (defined as average of width and height of receptive field) of cells in A1 (dark bars) and V1 (light bars). Receptive field sizes in A1 (mean $=10.9^{\circ}$, solid arrowhead) are significantly larger $(p<0.0001)$ than those in V1 (mean $=3.9^{\circ}$, open arrowhead). B, Distribution of receptive field locations recorded in Al (solid circles) and V1 (open squares). In A1, significantly many more fields were recorded representing peripheral regions of the visual field white noise. These same auditory stimuli produced robust responses in normal $\mathrm{A} 1$ ( $n=37$ in one normal ferret).

We have not attempted to conduct a laminar analysis of our data. However, visual units were recorded throughout cortical layers in both $\mathrm{A} 1$ and $\mathrm{V} 1$ : cells were recorded throughout the $\approx 1 \mathrm{~mm}$ thickness of ferret Al (Roe, 1991).

\section{Differences between response features of cells in $A 1$ and $V 1$}

There were three major differences between the characteristics of visual units in A1 and V1: responsivity, receptive field size, and latency to optic chiasm stimulation. As will be discussed later, these differences appear to arise primarily from the properties of retinal and thalamic input to Al and V1.

\section{Responsivity}

One salient difference between visual units in Al and Vl was their responsiveness to visual stimulation. Most cells in V1 responded in robust and consistent fashion to visual stimuli. In contrast, cells in Al were much more difficult to drive, exhibited labile responses, and responded with fewer spikes. Cells were qualitatively rated, during recording, on a four-point scale, where 1 indicates poor responsiveness and 4 good responsiveness. This index reflects both robustness (qualitative determination of response strength, i.e., number of spikes) as well as reliability of response. (Units that were responsive only to electrical stimulation were not rated; $38 \mathrm{Al}$ cells recorded in early experiments also were not rated.) Of $105 \mathrm{~V} 1$ cells and $156 \mathrm{Al}$ cells that were rated, $93 \%$ of units in V1 were rated 4 and $68 \%$ of units in $\mathrm{Al}$ were rated 1 (Fig. 1). The poorer responsivity of Al cells often made receptive field characterization of $\mathrm{A} 1$ cells difficult and time consuming; proportionally fewer cells in Al were fully characterized as a result (see Table 1).

\section{Receptive field size}

A second prominent difference between Al and V1 cells was the size of their receptive fields. Receptive field sizes (calculated as the average of the length and width of the receptive field) of visual cells in Al were significantly larger than those of VI cells, their mean diameter (mean $=10.9^{\circ}, n=87$ ) reaching almost three times that of $\mathrm{Vl}$ cells (mean $=3.9^{\circ}, n=101$ ) (Fig. 2A). Of the cells in $A 1,64 \%$ had receptive fields larger than the largest receptive fields recorded in $\mathrm{V} 1$. In addition, $13 \%$ of cells in Al had receptive fields that were large $\left(15-30^{\circ}\right.$ in diameter) and whose borders were difficult to determine precisely (Fig. $2 A$, large, diffuse; not included in calculation of mean).

The difference in the receptive field sizes were not eccentricity related. The receptive field eccentricities of cells recorded in Al were significantly different from those of cells recorded in $\mathrm{V} 1$ $(p<0.0001$, Mann-Whitney $U$ test) (Fig. $2 B)$, consistent with the inuch flatter distribution of visual field magnification in Al compared to V1 (Roe et al., 1990a). However, receptive field sizes in A1 were still larger $(p<0.0001)$ when eccentricitymatched $\left(<30^{\circ}\right)$ populations were compared (Fig. $2 C$ ). This was also true for eccentricity-matched samples below $15^{\circ}(\mathrm{Al}, n=$

than in V1 $(p<0.0001) . C$, Taking into consideration only receptive fields whose eccentricities are less than $30^{\circ}$ reveals that $\mathrm{Al}$ cells still have much larger receptive fields $\left(\mathrm{A} 1\right.$ mean $=9.7^{\circ}, \mathrm{V} 1$ mean $=3.9^{\circ}, p$ $<0.0001)$. 
A

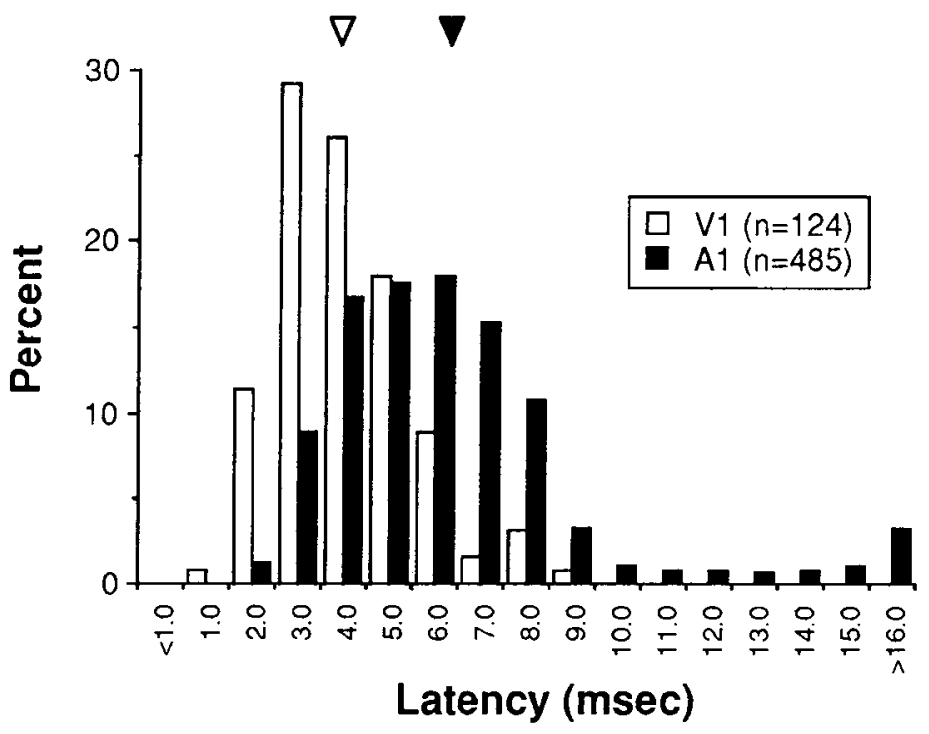

D

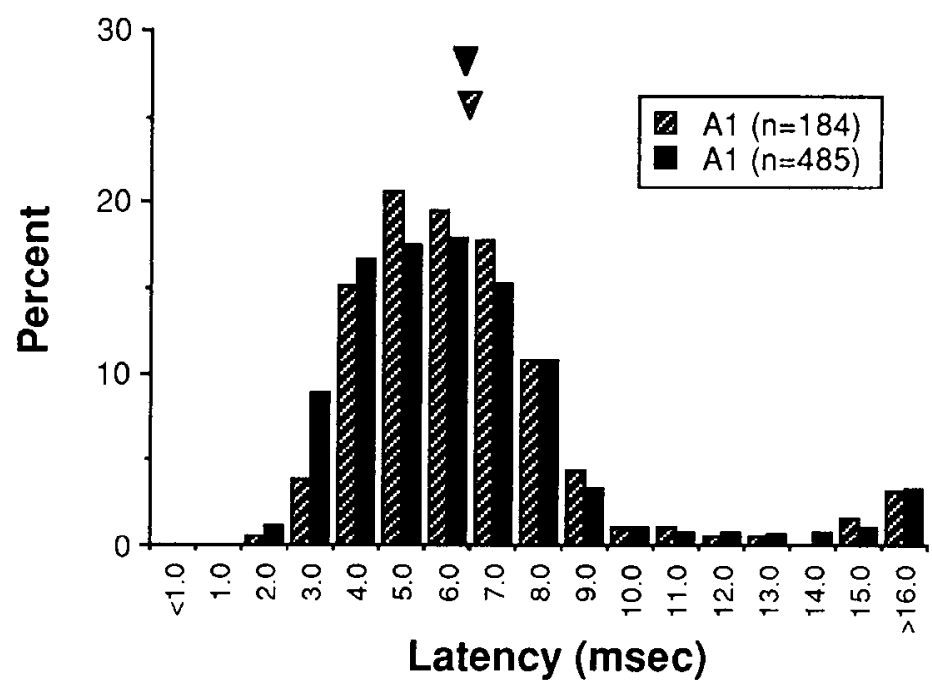

Figure 3. Latencies of cells in Al and $\mathrm{V} 1$ to electrical stimulation of the optic chiasm. $A$, Cells in Al (dark bars, $n=$ 485 , mean $=6.8 \mathrm{msec}$ ) have significantly longer latencies to chiasm stimulation than those in V1 (light bars, $n$ $=124$, mean $=4.4 \mathrm{msec})(p<0.0001)$. $B$. Latencies of visually responsive cells in $\mathrm{Al}$ (shaded bars, $n=184$, mean = $6.9 \mathrm{msec}$ ) are similar to those of all cells recorded in $\mathrm{A} 1(p>0.13)$. C, Similarly, visually responsive cells in VI (shaded bars, $n=77$, mean $=4.3 \mathrm{msec}$ ) have latencies similar to all cells recorded in VI $(p>0.7)$.

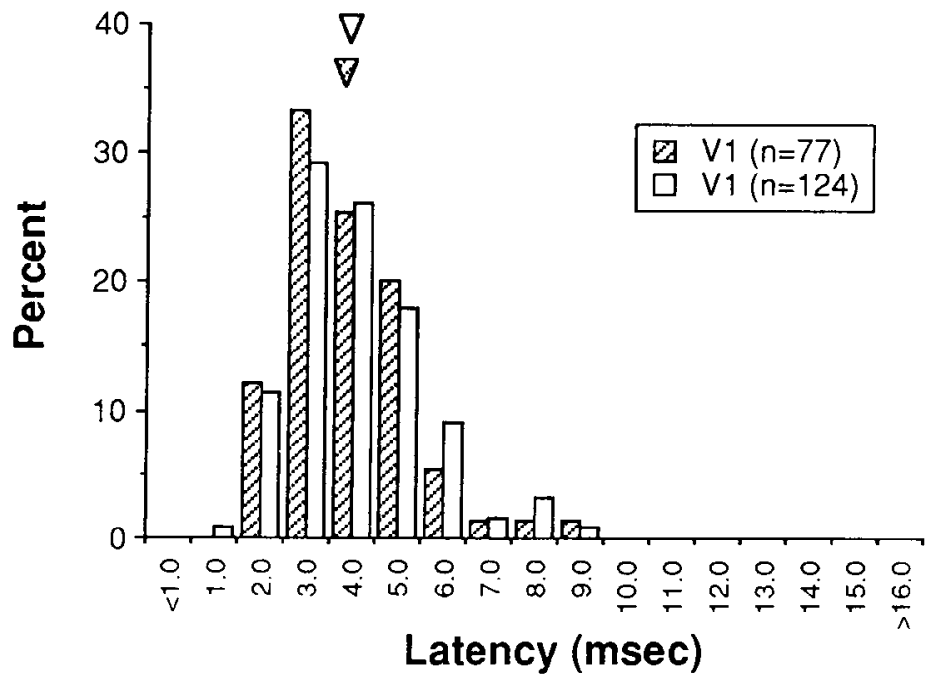


18; V1, $n=53 ; p<0.0001)$ and below $45^{\circ}(\mathrm{A} 1, n=78 ; \mathrm{V} 1, n$ $=101 ; p<0.0001$ ).

\section{Conduction latency of afferents}

Cells in Al and V1 also differed in their latencies to optic chiasm stimulation. When the latencies of all cells in $\mathrm{Al}$ and $\mathrm{V} 1$ were compared (Fig. $3 \mathrm{~A}$ ), those recorded in $\mathrm{Al}$ (mean $=6.8 \mathrm{msec}$ ) were significantly longer than those in V 1 (mean $=4.4 \mathrm{msec} ; p$ $<0.0001$ ). In both $\mathrm{A} 1$ (Fig. $3 B$ ) and V1 (Fig. 3C), the latencies recorded for the subpopulation of visually responsive cells (Al, $n=194 ; \mathrm{VI}, n=77$ ) were representative of all units recorded. There was no correlation between the latency to optic chiasm stimulation and cortical depth, receptive field size, or responsivity.

\section{Similarities between cells in A1 and $\mathrm{V} 1$ : integrative features of receptive fields}

Of the visual cells recorded in Al of rewired ferrets, a portion were sufficiently responsive to allow further characterization, including determination of cell class, ocular dominance, and orientation, direction, and velocity selectivities. As mentioned previously, reliably responding visual cells were much more frequently encountered in $\mathrm{V} 1$ than in $\mathrm{Al}$; this difference is reflected in the higher percentage of cells in V1 $(25 \%, n=38)$ than in $\mathrm{Al}(5 \%, n=24)$ whose responses were quantified.

\section{Ocular dominance}

To determine a cell's ocular dominance, we compared (with an audio monitor) the ipsilateral and the contralateral monocular responses to visual stimulation of its receptive field. We subsequently rated the cell on a scale from 1 to 7 , with 1 indicating complete contralateral dominance, 7 complete ipsilateral dominance, and 4 equal dominance by the two eyes (Hubel and Wiesel, 1962). In V1, we recorded predominantly contralaterally dominated cells (Fig. 4): $65 \%$ of all units tested exhibited complete contralateral ocular dominance (OD group 1) and only $10 \%$ exhibited an ipsilateral dominance (OD group 5, 6, or 7). [A few cells $(\mathrm{n}=3)$ to which we did not give an ocular dominance rating were not responsive to monocular stimulation but exhibited clear responses to binocular stimulation.] This contralaterally biased visual representation in the mustelid visual cortex has been previously reported and is due to both an extensive monocular segment as well as a true contralateral bias in the binocular segment (LeVay et al., 1987; Law et al., 1988; Zahs and Stryker, 1988; Redies et al., 1990).

In $A 1$, a similar ocular dominance distribution was seen: $66 \%$ of the visual cells rated were completely contralaterally dominated (OD group 1) and 7\% exhibited ipsilateral preference (OD group 5, 6, or 7). Approximately $30 \%$ of units recorded in both A1 and V1 are binocular (OD groups 2-6). These two ocular dominance distributions are not significantly different $\left[\chi^{2}(0.95)\right.$ $=4.6, \mathrm{df}=6 \mathrm{]}$.

Cells recorded in $\mathrm{Al}$ and $\mathrm{V} 1 \mathrm{with}$ any ipsilateral contribution had receptive fields in the binocular segment. The receptive fields of five cells in V1 (one contralaterally, two ipsilaterally, two binocularly driven) and five cells in Al (all contralaterally driven) fell in the ipsilateral hemifield. This may be a reflection of inappropriate location of some retinal ganglion cells with respect to the nasotemporal division in the ferret retina (Vitek et al., 1985).

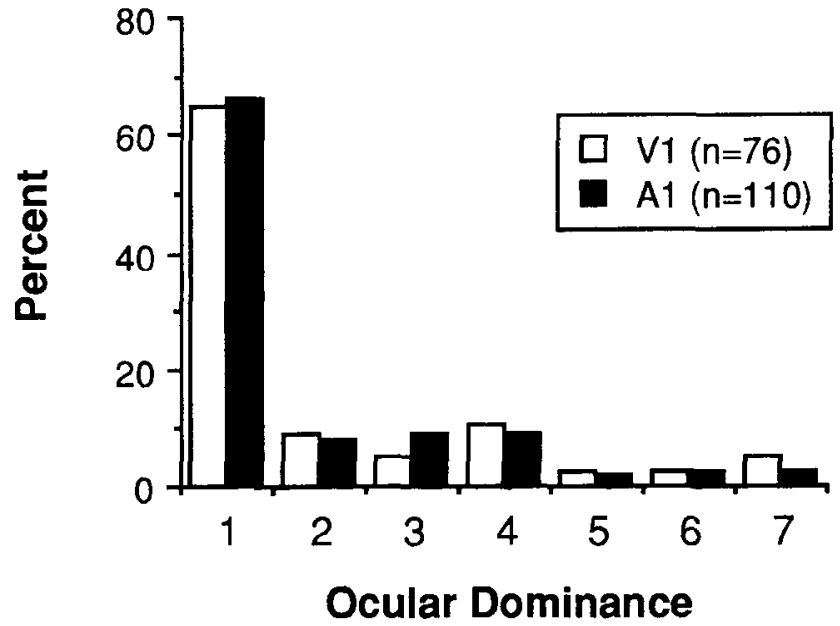

Figure 4. Ocular dominance distributions of visual cells recorded in A1 (dark bars) and in V1 (light bars). These two distributions are not significantly different $\left[\chi^{2}(0.95)=4.6, \mathrm{df}=6\right]$.

\section{Receptive field types}

$V I$ cells. Receptive fields of cells in V1 of normal ferrets were classified as simple or complex, if oriented, or as nonoriented, and in general resembled those described previously in cats (Hubel and Wiesel, 1962), minks (LeVay et al., 1987), and ferrets (Law et al., 1988). Most simple cells $(n=20)$ exhibited two or three spatially segregated contrast-specific subfields, responding to either onset or offset of optimally oriented flashing bars and or to moving light or dark contrast edges of optimal orientation. Responses within a single subfield exhibited spatial summation to flashing bars of increasing size. Some cells that we classified as simple $(n=4)$ exhibited spatial summation but had only a single on or off region (see Zahs and Stryker, 1988; cf. Palmer and Davis, 1981; Schiller et al., 1976a). Complex cells $(n=50)$ had only a single oriented response field to flashing bars or moving contrast edges of the appropriate orientation and typically responded to both the onset and offset of light and/or to edges of either light or dark contrast. Complex cells typically were equally responsive to small as well as large bars within their receptive fields. Two cells that we classified as complex responded only to very small moving or flashing oriented bars within their receptive fields and were silenced by bars illuminating the entire receptive field. These cells may correspond to "special complex" cells described in previous studies (Palmer and Rosenquist, 1974; Gilbert, 1977). End-inhibition was seen in both simple $(n=8)$ and complex cells $(n=10)$. Nonoriented cells $(n=27)$ had either circular or elongated receptive fields with weak or absent inhibitory surrounds.

Al cells. In A1, as mentioned above, receptive fields were larger. In general, receptive field organization was somewhat more difficult to determine due to weakness and lability of rcsponse. Despite this, similar receptive field structures were observed. We were able to classify approximately one-half ( 52 of 100) of the cells in Al as simple, complex, or nonoriented. Similar to cells in V1, simple cells in A1 $(n=16)$ displayed orientation selectivity and had one $(n=4)$, two $(n=6)$, or three $(n=4)$ spatially segregated subfields. Borders between subfields were not as sharp as those in V1, but were nonetheless clearly present. Complex cells $(n=24)$ were oriented, exhibited either on-, off-, or on/off-responses throughout their receptive fields, 


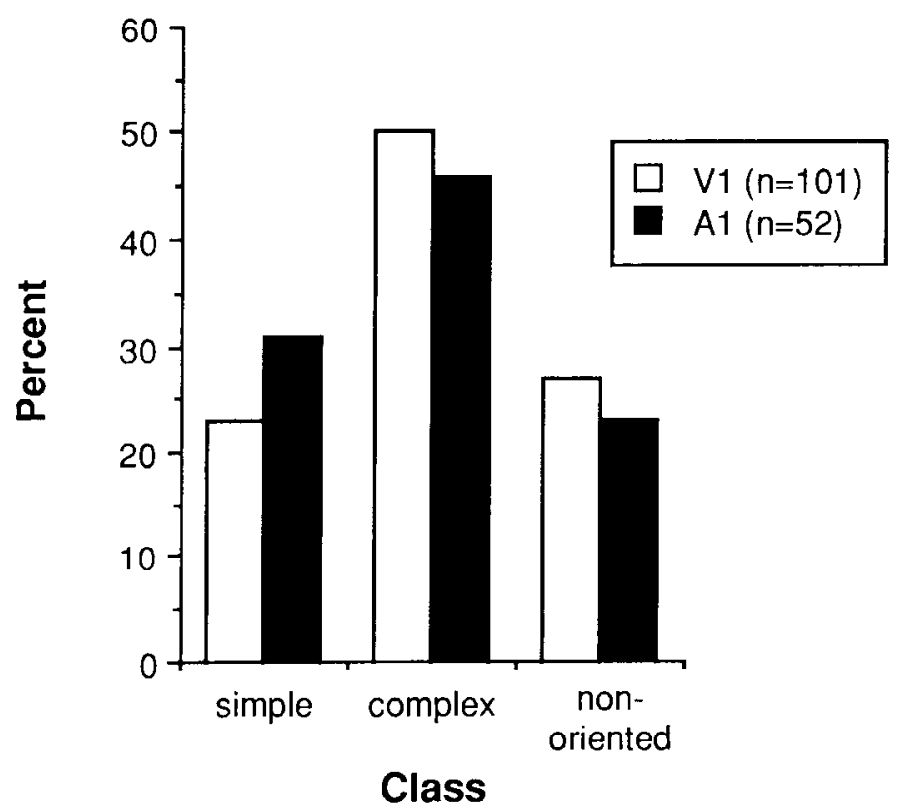

Figure 5. Percentage of simple, complex, and nonoriented cells in Al (dark bars) and V1 (light bars). These distributions are not significantly different $\left[\chi^{2}(0.95)=3.7\right.$, df $\left.=2\right]$.

and responded equally well to small and large bars. End-stopping was seen in one simple and five complex cells. In one case (a simple cell), the degree of end-inhibition was quite dramatic: extending a light bar by $10 \%$ beyond the receptive field border reduced the cell's response by $50 \%$. Nonoriented receptive fields $(n=12)$ were either circular or elongated with weak or absent inhibitory surrounds.

Relative proportions. Not only do simple, complex, and nonoriented cell types occur in A1, they also occur in proportions similar to that found in V1. In both the Al and the V1 populations recorded, approximately $50 \%$ of the cells were complex, $25 \%$ simple, and 25\% nonoriented (Fig. 5). While we do not claim that these figures reflect actual cell class composition in Al and V1, at no time did we attempt to "find" cells of any particular class. Our sampling was based solely on units with appropriate strength and consistency of response. We found no statistically significant correlations, in either A1 or V1, between receptive field type and receptive field size, latency to optic chiasm stimulation, or depth. Neither were there any correlations between cell type and orientation, direction, or velocity selectivities (see also below).

\section{Tuning characteristics of single units in $A l$ and $V I$}

To determine orientation tuning, we first examined responses to flashing bars at various orientations. For cells not responsive to standing flashes, we made a qualitative assessment of orientation selectivity with moving or "jiggling" bars or moving edges. We also tested the response to moving spots; however, moving spots were generally not an effective stimulus. For quantitative determination of orientation selectivities, moving bars were used as stimuli and polar plots made of the responses. In almost all cases, quantitative characterization of the optimal orientation agreed with our qualitative assessment. For some cells in A1, quantitative collection of spikes in response to multiple stimulus sweeps revealed orientation tuning not obvious from responses to single sweeps assessed by ear.
An example of an orientation selective cell in $\mathrm{V} 1$ is shown in Fig. $6 A$. This cell is a simple cell and responds optimally to a bar oriented at $-45^{\circ}$ from vertical, sweeping in either direction. A second example is shown in Fig. $6 B$. This complex cell prefers bars oriented at $+45^{\circ}$ from vertical and is slightly directional for upward movement.

Cells in Al were also characterized similarly. Fig. $7 \mathrm{~A}$ illustrates the orientation selectivity of a nondirectional simple cell in Al that preferred horizontally oriented bars. A directionally selective simple cell is shown in Fig. $7 B$. This cell responds best to downward-sweeping bars oriented $30^{\circ}$ from vertical. As can be seen from these plots, cells in Al respond with fewer spikes overall than those in $\mathrm{Vl}$ and their responses appear to be modulated less strongly with respect to background levels.

Orientation tuning. The orientation tuning of 38 cells in V1 and 24 cells in A1 was studied quantitatively. For each of these cells, two measures of orientation tuning were calculated: orientation selectivity and orientation tuning width. The orientation selectivity index is defined as: 1 - (orthogonal response/ best response) (cf. Felleman and Van Essen, 1987). A cell whose response in the best orientation is twice the level of that to the orthogonal orientation would have an orientation selectivity of 0.5 ; one whose best response is 1.5 times that in the orthogonal orientation would have a selectivity of 0.33 . We have considered those units with selectivities below 0.3 to be unoriented, those with selectivities from 0.3 to 0.5 to be weakly oriented, and those with selectivities above 0.5 to be strongly oriented. Both A 1 and V1 contained cells exhibiting a range of orientation tuning selectivities, ranging from unoriented to strongly oriented. In fact, no significant difference was seen in the distribution of orientation strengths of cells in $\mathrm{Al}$ and V1 (Fig. 8A). Of oriented cells, approximately $40 \%$ of units in Al (three simple, six complex) and V1 (six simple, eight complex) were sharply oriented (selectivity $>0.5$ ), while $33 \%$ of units in Al (five simple, three complex) and $26 \%$ in VI (three simple, seven complex) were broadly oriented (selectivity $0.3-0.5$ ).

Orientation tuning widths (defined as the width of the orientation tuning curve at $1 / \sqrt{2}$ peak height) were also determined. For both $\mathrm{Al}$ and $\mathrm{Vl}$ cells, orientation tuning widths ranged from narrow tuning $\left(<30^{\circ}\right)$ to very broad tuning $\left(>90^{\circ}\right)$ (Fig. $8 B$ ). While a greater percentage of cells in $\mathrm{V} 1$ than in $\mathrm{Al}$ had tuning widths of $30^{\circ}-59^{\circ}$, these distributions were not significantly different. Thus, neither measure of orientation tuning revealed any quantitative difference between $\mathrm{Al}$ and $\mathrm{VI}$ with respect to orientation tuning.

Direction selectivity. A directionality index was calculated from the responses obtained at the preferred orientation of each cell; this index was defined as 1 - (nonpreferred/preferred response). The frequency distribution of these values in $A 1$ and $V 1$ also proved to be similar (Fig. 9). Interestingly, V 1 contained a higher proportion $(40 \%)$ of nondirectional (directional selectivity < $0.3)$ cells than Al $(21 \%)$. Al also contained a greater proportion $(25 \%)$ of highly directional cells (selectivity $>0.6)$ than Vl (15\%). Overall, however, the two distributions were not significantly different $(0.1<p<0.5)$. No relationship was seen between cell class and directionality in either Al or V1: directionality strengths for each of the simple, complex, and nonoriented cells classes ranged from nondirectional to highly directional.

Velocity selectivity. One of the more unexpected findings of this study was that the velocity tuning of cells in Al were similar to those of cells in V1. The velocity selectivity of each cell was 


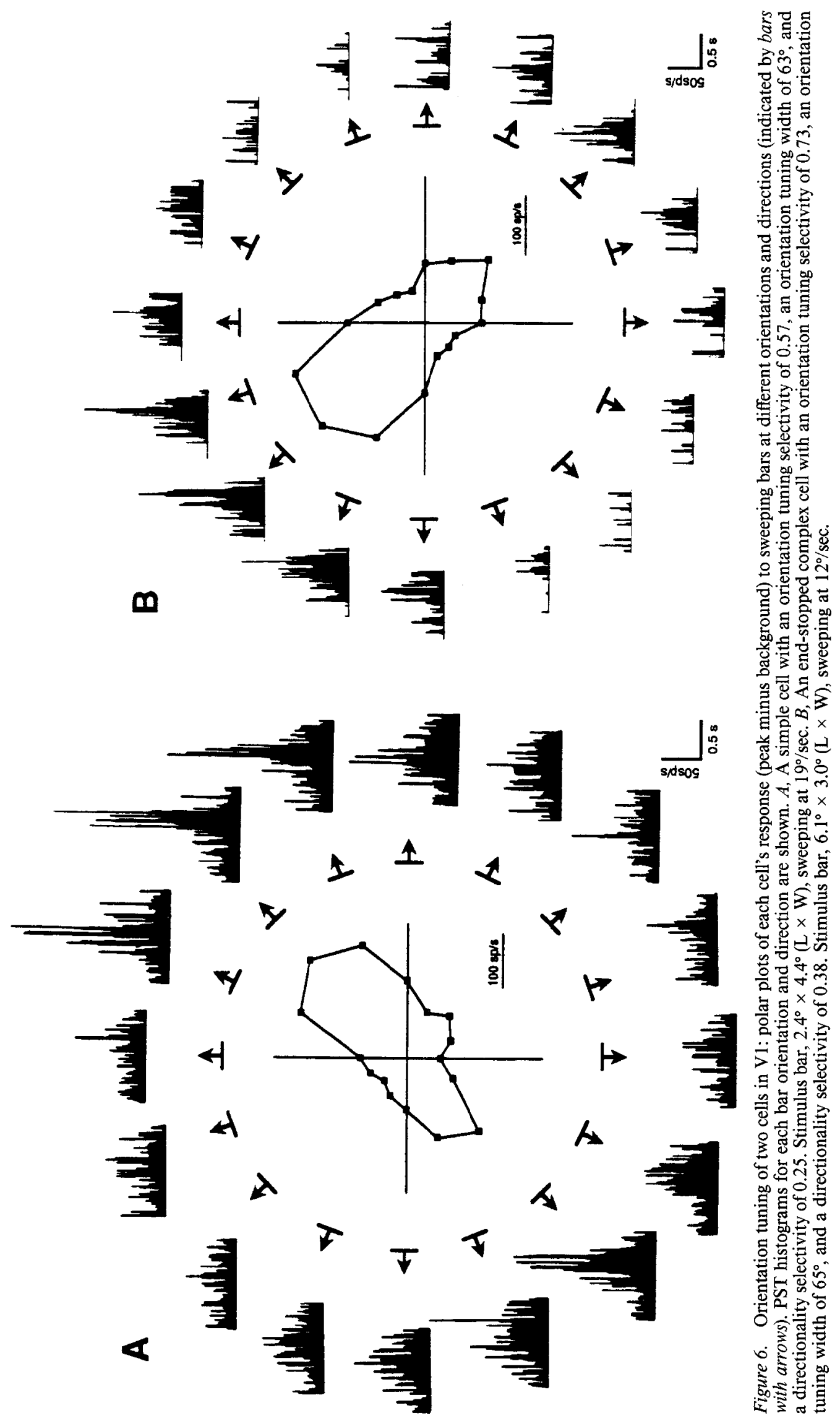




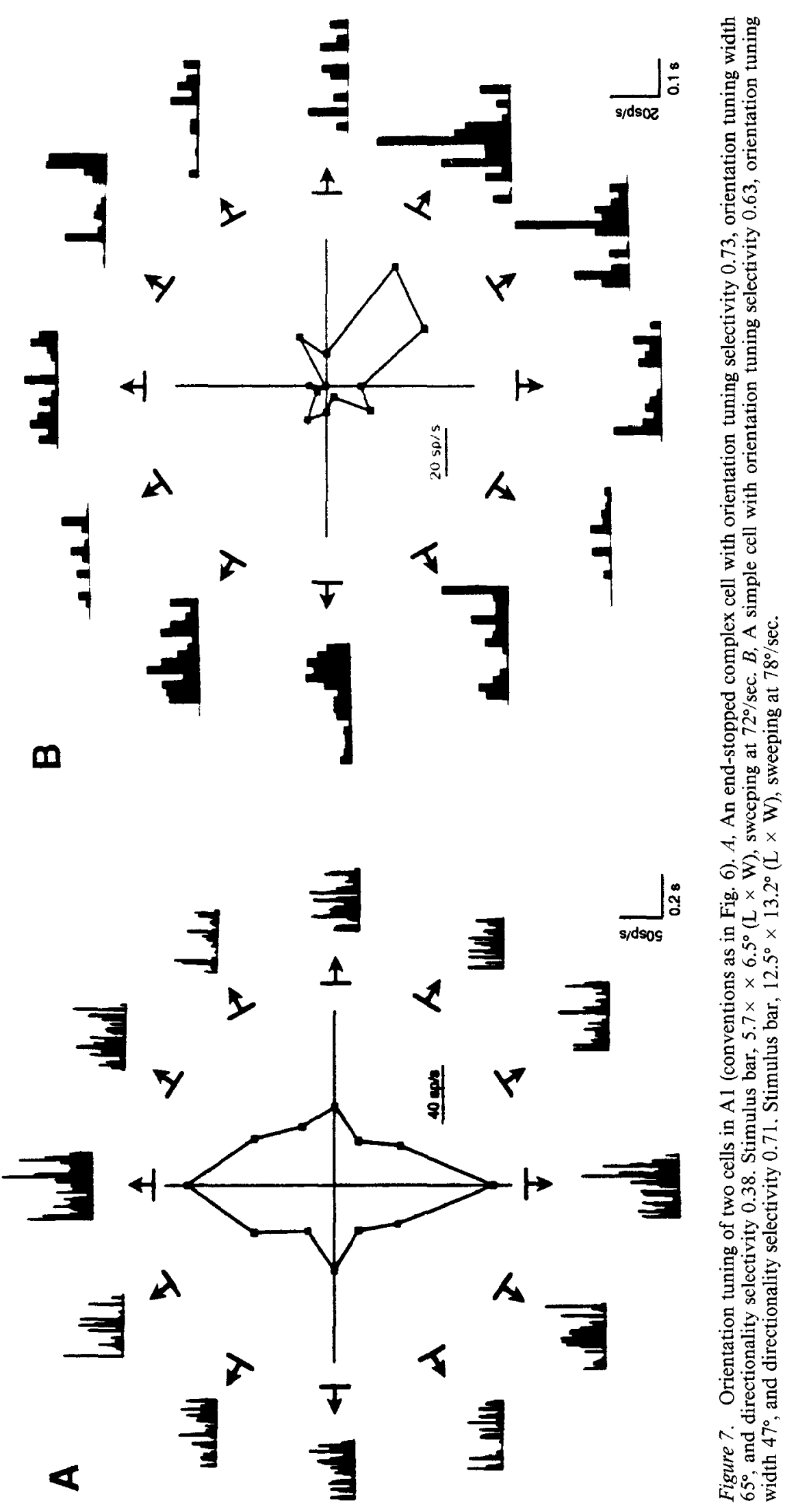


A

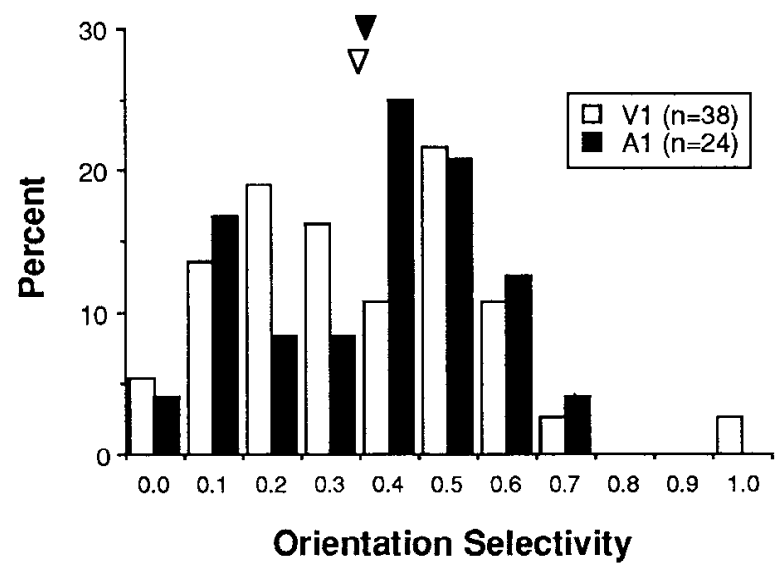

B

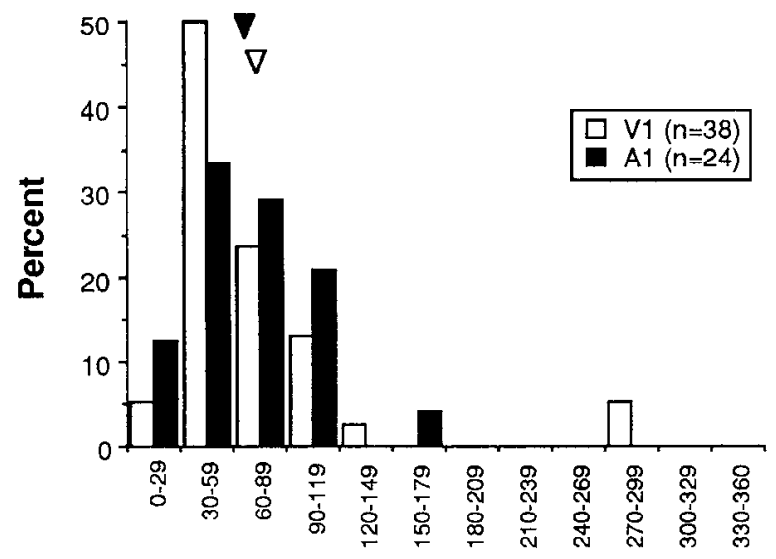

Orientation Width $\left({ }^{\circ}\right)$

Figure 8. Orientation tuning of cells in A1 (dark bars) and in V1 (light bars). $A$, Distributions of oricntation tuning sclectivitics in $\mathrm{Al}$ (mean $=0.41)$ and VI (mean $=0.39)$ are similar $(p>0.65) . B$. Distributions of orientation tuning widths (defined as width at $1 / \sqrt{2}$ height) in Al $\left(\right.$ mean $\left.=65.3^{\circ}\right)$ and $\mathrm{V}_{1}\left(\right.$ mean $\left.=72.5^{\circ}\right)$ are not different $(p>0.90)$.

studied by collecting responses to optimally oriented light stimuli swept at several velocities, generally between $5 \% \mathrm{sec}$ and $100 \%$ sec, over its receptive field; $29 \mathrm{~V} 1$ cells ( 9 simple, 11 complex, and 9 nonoriented) and $18 \mathrm{Al}$ cells (6 simple, 9 complex, and 3 nonoriented) were studied in this fashion. The stimulus orientation chosen for nonoriented cells was arbitrary.

Examples of velocity tuning preferences are shown in Fig. $10 A$ (A1, right column; V1, left column) and are similar to those previously described in cat visual cortex (e.g., Orban et al., 1981). Most cells were tuned to either slow $(<15 \%$ sec, curves 1 and 2 ), medium ( $15-50 \%$ sec, curves 3 ), or fast ( $>50 \%$ sec, curves 4) velocities. Some cells exhibited velocity high-pass or lowpass characteristics (curves 5; see also curves 1 ). We recorded a few cells that responded equally well to slow and to fast, but not to medium, stimulus velocities (curves 6). Cells exhibiting broad tuning were also encountered (curves 7). Thus, cells in both $\mathrm{A} 1$ and $\mathrm{V} 1$ exhibited a range of velocity tuning. Furthermore, the velocity tuning distributions were found to be similar in these two areas: approximately $45 \%$ of the cells recorded in A1 and V1 were best tuned to slow, 35\% to medium, and less than $10 \%$ to fast velocities (Fig. 10B). No consistent relationship was seen between velocity tuning and cell type.

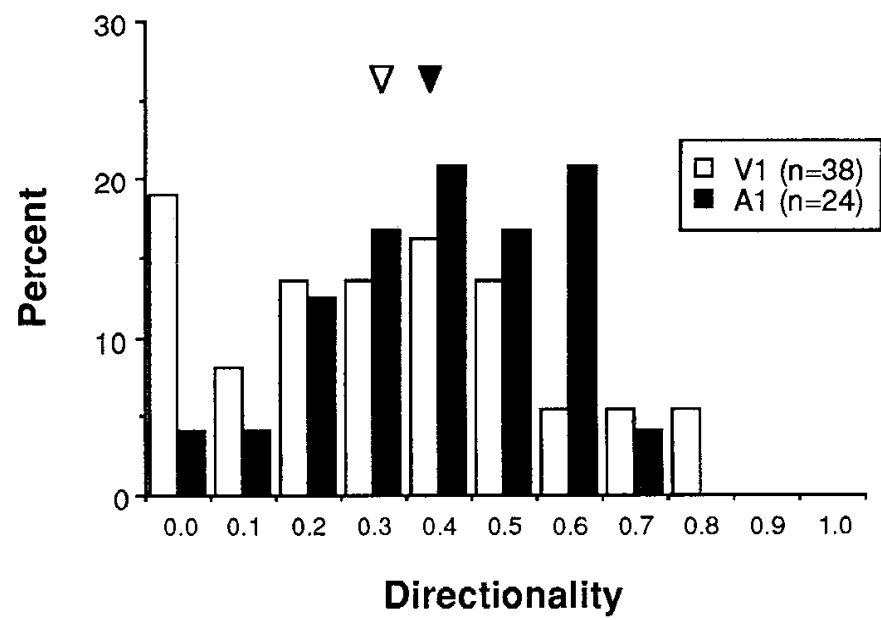

Figure 9. Directionality of cells in A1 (dark bars) and in V1 (light bars). $\mathrm{Al}$, mean $=0.45 ; \mathrm{V} 1$, mean $=0.36$. The two distributions are not significantly different $(0.1<p<0.5)$.

\section{Discussion}

Our goal in this study has been to explore the developmental and functional specificity of mammalian cerebral cortex. Toward this goal, we have challenged $\mathrm{Al}$ in ferrets with visual input and studied the resulting visual processing in Al. Previously, we reported that retinal projections can be induced to innervate auditory thalamus in ferrets following specific neonatal lesions (Sur et al., 1988; cf. Schneider, 1973). These projections, which appear to arise primarily from retinal ganglion cells of the W cell class, provide visual input to cells in Al (Sur et al., 1988; Pallas et al., 1990; Roe et al., 1990a; Roe, 1991). In this article we have characterized in detail the receptive field properties of visually responsive cells in Al of rewired ferrets and have compared them both qualitatively and quantitatively to visual cortical cells recorded in V1 of normal ferrets. We find that receptive field properties of visual cells in rewired Al bear remarkable similarities to those in normal $\mathrm{V} 1$. We will first summarize and discuss the generation of these receptive field properties in $\mathrm{Al}$ and then turn to two possible interpretations of these results.

\section{Generation of visual receptive field properties in A1 \\ Sources of visual input to $A 1$}

It is important to consider at the outset what the sources of visual input to $\mathrm{Al}$ are in rewired ferrets. It is possible, for example, that there are novel corticocortical projections to A1 in rewired animals that arise from remaining unlesioned visual cortical areas, and that certain features of visual integration (such as orientation selectivity, direction selectivity, and binocularity) are already prescnt in thesc cortical inputs. The issue has been addressed by making injections of retrograde tracers into $\mathrm{A} 1$ in rewired ferrets, and comparing the cortical and thalamic inputs with those to Al in normal ferrets (Pallas et al., $1988,1990)$. In brief, the cortical areas that project to Al in rewired animals are the same areas that project to $A 1$ in normal animals, and do not include any visual cortical areas.

The overwhelming proportion of thalamic input to $\mathrm{A} 1$ in rewired animals arises from the MGN (Pallas et al., 1990). In addition, a sparse input arises from the lateral posterior (LP)/ pulvinar complex to Al in rewired ferrets (Pallas et al., 1990). It is unlikely that these $\mathrm{LP} /$ pulvinar projections contribute to 
Figure 10. A, Examples of velocity tuning curves in VI (left column) and A1 (right column). In each column, curves 1 and 2 are tuned for slow $(<15 \%$ sec), curves 3 for medium $(15-50 \% / \mathrm{sec})$, and curves 4 for fast $(>50 \% / \mathrm{sec})$ velocities. Curves 5 display high-pass or lowpass, curves $6 \mathrm{U}$-shaped, and curves 7 broad-band velocity characteristics. $B$ (opposite page), Distributions of cells in A1 (dark bars) and V1 (light bars) displaying peak velocity preferences near $6 \% \mathrm{sec}, 13 \% \mathrm{sec}, 25 \% / \mathrm{sec}, 50 \% \mathrm{sec}, 100 \%$ sec, as well as those displaying broadband $(B B)$ and U-shaped (slow/fast) tuning curves. These distributions are not significantly different $(p>0.8)$. A1 mean $=27.9^{\circ} / \mathrm{sec} ; \mathrm{V} 1$, mean $=24.6 \%$ sec.

A

V1

A1

1

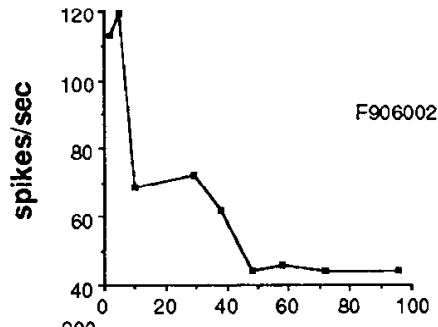

2

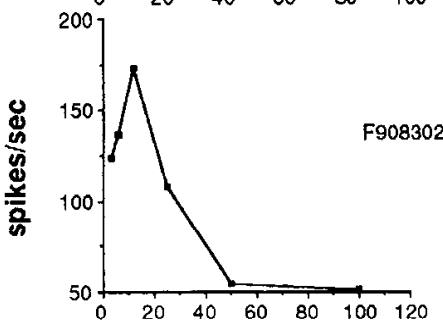

3

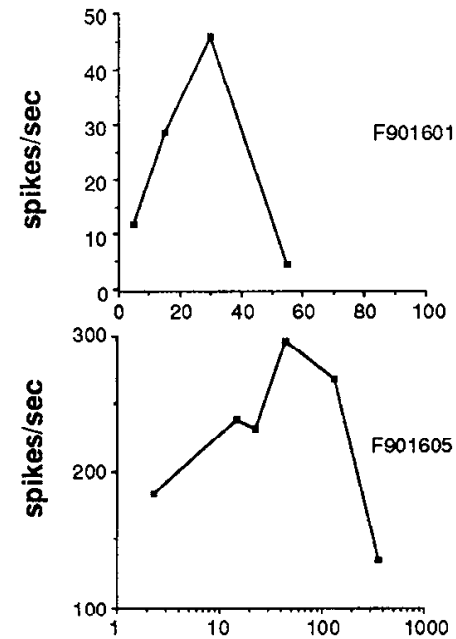

5

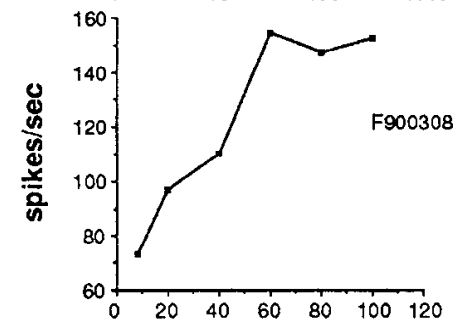

6

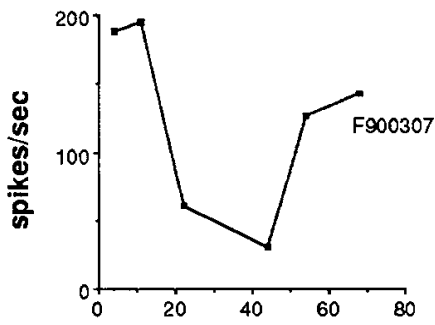

7

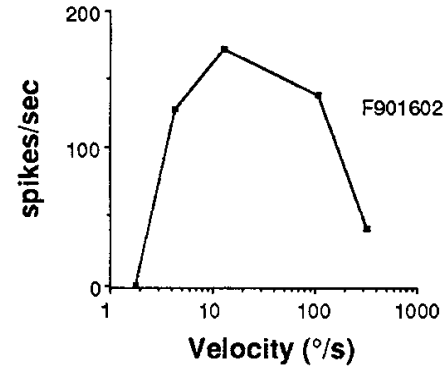

F895903
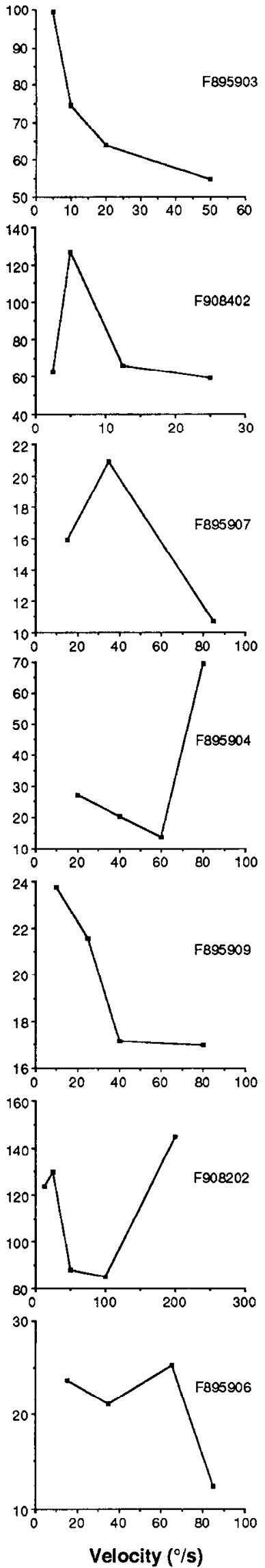


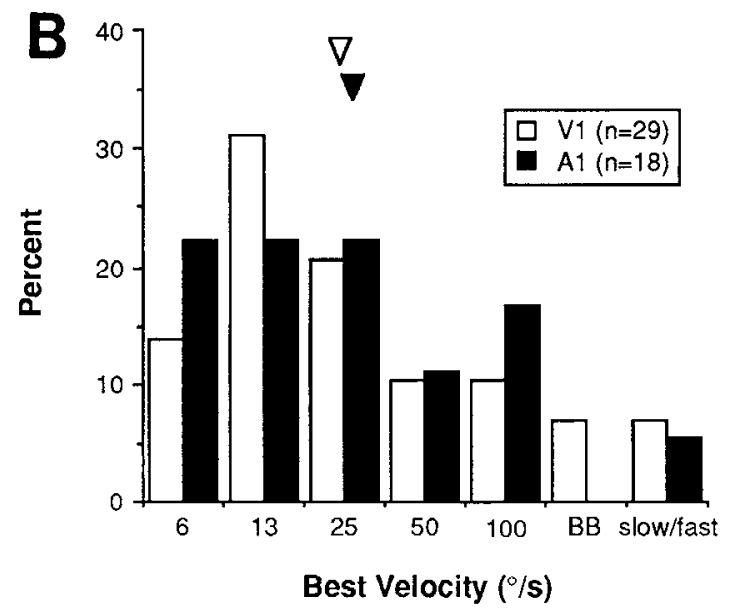

Figure 10. Continued.

the visual responses of $\mathrm{A} 1$ neurons since (1) these projections are much sparser than the projections from the MGN, (2) they arise from cells that lie deep within the LP/pulvinar region and that show almost no overlap with retinal projections in these animals, and (3) ibotenic acid lesions of the MGN abolish previously visually responsive recording sites in $\mathrm{Al}$ and similar lesions of the LP/pulvinar complex do not (S. L. Pallas, L. Toth, and M. Sur, unpublished observations).

\section{Contribution of retinal inputs}

Our results show that visual cells in $\mathrm{Al}$ are poorly responsive and have large receptive field sizes and long latencies to optic chiasm stimulation. These characteristics are already present in and can be predicted by the retinal and thalamic input to A1. We have suggested previously that the auditory thalamus in rewired ferrets receives retinal ganglion cell input of the $\mathrm{W}$ cell type (Roe et al., 1987; Sur et al., 1988; Pallas et al., 1989; Roe, 1991). Retinal W cells have "sluggish" responsiveness to visual stimuli and are characterized by large, often diffuse, receptive fields, some of which have center-surround organization but many of which do not (Wilson et al., 1976; Fukuda et al., 1984; Stanford, 1987). Similar receptive field properties are found in postsynaptic visual cells in the MGN in rewired ferrets (Sur et al., 1988; Roe, 199 1). Large receptive field sizes of Al cells may be due to both the $\mathrm{W}$ cells that form the retinal source of inputs and to the pattern of highly convergent and divergent thalamocortical connectivity typical of the auditory system and shown to be retained in these rewired ferrets (Pallas et al., 1990; cf. Andersen et al., 1980; Middlebrooks and Zook, 1983). The poor responsivity of cells in Al is consistent with its W type input (Sur and Sherman, 1982). In addition, we cannot rule out abnormal synaptic configurations of retinal axons on MGN cells or additional inhibitory mechanisms within MGN or Al that decrease the responsiveness of $\mathrm{MGN}$ and Al cells in rewired animals. Retinal W cells also have slowly conducting, poorly myelinated axons (Cleland and Levick, 1974a,b) consistent with the relatively long latencies to optic chiasm stimulation found both in the MGN (Sur et al., 1988) and in Al.

\section{Contribution of intracortical mechanisms: similarity of rewired Al to normal VI}

Single cells in Al exhibit aspects of receptive field organization, orientation selectivity, and direction selectivity absent in visual cells in the MGN. Visual cells in the MGN have circular or elongated receptive fields; these cells lack orientation selectivity and exhibit lower degrees of direction selectivity than visual cells in A1 (Sur et al., 1988; Roe, 1991). These findings parallel patterns of receptive field generation in the normal visual pathway through the LGN to area 17 in the ferret (Esguerra et al., 1986; Price and Morgan, 1987; Roe et al., 1989). While a limited degree of orientation bias may be present at the retinal or thalamic level (e.g., Leventhal et al., 1990), the generation of a marked degree of orientation and direction selectivity is believed to occur intracortically (e.g., Sillito, 1975). Direction selectivity is affected following sclective lcsions of supcrficial cortical layers (Eysel et al., 1987). These cortical receptive field properties of $\mathrm{V} 1$ and $\mathrm{Al}$ cells are thus likely to arise from intracortical circuits common to both V1 and visually innervated A1. In our recordings from normal $\mathrm{V} 1$ as well as from rewired $A 1$, we found a fairly large proportion $(\approx 25 \%)$ of nonoriented cells (Fig. 5). There appears to be a true species difference between ferret and cat visual cortex in terms of the prevalence of nonoriented cells. While visual cortex in cats (Hubel and Wiesel, 1962) and mink (LeVay et al., 1987) has few nonoriented cells, approximately one-quarter of cells recorded in ferret V1 are nonoriented. A previous study of receptive fields in ferret V1 reported only that "most single neurons . . . were orientationselective" (Law et al., 1988). It is unlikely that our nonoriented cells represent recordings from geniculocortical afferents, since (1) afferents were recognized by their higher level of spike activity, (2) nonoricnted units wcre clcarly distinguished as cell spikes rather than axon spikes, and (3) nonoriented units were recorded at all depths in the cortex. While it is possible that some of the recording sites were influenced by multiunit activity, the presence of orientation selectivity would still be detected at such sites since visual cortical cells within a single columnar locale share similar orientation selectivities (LeVay et al., 1987; Law et al., 1988; Redies et al., 1990).

The marked degree of similarity between $\mathrm{Al}$ and $\mathrm{Vl}$ is apparent not only in the orientation, direction, and velocity selectivity of cells but also in the types of receptive field organizations found there. As in V1, Al contains simple and complex (and nonoriented) receptive field types and in roughly similar proportions. These findings are somewhat surprising in view of the fact that $\mathrm{Al}$ and $\mathrm{Vl}$ receive significantly different types of input from the retina. $\mathrm{V} 1$ in normal cats and ferrets is dominated by $X$ and $Y$ cell inputs from the retina relayed through the LGN. Previous studies devoted to examining the contribution of $\mathrm{X}$ and $Y$ cell inputs to receptive field properties of simple and complex cells in primary visual cortex have shown that neither the simple nor the complex cell classes are exclusively $\mathrm{X}$ - or Y-cell driven (Malpeli et al., 1981; Tanaka, 1983; Mullikin et al., 1984; Ferster 1990a,b). Given that visual inputs to A1 arise from retinal $W$ cells (Roe, 1991), the results of this study demonstrate that (1) $\mathrm{X}$ and $\mathrm{Y}$ cell inputs are not necessary, and (2) W cell input is sufficient, for the generation of simple and complex receptive field types. The finding that similar orientation tuning selectivities can be generated in A1 and VI further increases the likelihood that such tuning properties are generated intracortically and are relatively independent of specific visual input characteristics. We argue, therefore, that the generation of these cortical receptive field organizations and tuning propertics is not dependent on input cell type (i.e., $X, Y$, or W) but arises via intracortical circuitries activated by a minimum of visual input. 


\section{Do inputs specify intracortical circuitry?}

A possible interpretation of these data is that visual input during development has actually instructed the establishment of specific cortical circuits in A1, which thereby exhibits the functional properties similar to those normally seen in V1. In this view, the temporal patterns of sensory activity unique to each sensory modality actively instruct the development of specific cortical circuits possibly from an initially naive cortical template. This is an attractive hypothesis in view of the significant literature on activity-dependent mechanisms during cortical development, and has been recently discussed in the context of this experimental preparation (Pallas, 1990; Sur et al., 1990).

It is clear that the development of functional properties of cells in primary visual cortex can be modificd by changes in visual input. Studies using abnormal visual rearing conditions (for review, see Sherman and Spear, 1982), blockade of retinal activity (Chapman et al., 1986; Stryker and Harris, 1986), and perturbation of postsynaptic activity (Kasamatsu and Pettigrew, 1979; Reiter and Stryker, 1988; Bear et al., 1990) during development have shown that changing the quality and quantity of activity can greatly influence the establishment of ocular dominance in visual cortex. Other cortical receptive field properties (such as orientation selectivity, direction selectivity, and receptive field organization) can also be affected by altering the visual environment. For example, binocular lid suture and dark rearing produce dramatic reductions in the number of cells with normal activity levels and normal orientation and direction tuning properties (Wiesel and Hubel, 1965; Pettigrew, 1974; Imbert and Buisseret, 1975). Rearing in striped environments of a single orientation results in a proportionally higher incidence of cells with similar orientation (Blakemore and Cooper, 1970; see, however, Movshon and Van Sluyters, 1981).

In this context, the functional similarity of visually innervated auditory cortex or somatosensory cortex (Frost and Metin, 1985; Metin and Frost, 1989) to normal visual cortex may be interpreted as the first functional demonstration of cross-modal induction of modality-specific cortical circuitry by peripheral input. If significant differences exist in the intracortical circuitry of normal V1 and normal A1, these findings would suggest that inputs do not simply influence, but actually instruct the establishment of cortical circuits. At the time that the lesions are made in the ferret, cerebral cortex is still quite immature. In primary visual cortex, only the deeper cortical layers (layers 4 , 5 , and 6) have migrated into place and geniculocortical afferents are still waiting in the subplate (McConnell, 1988; Peduzzi, 1988; Jackson et al., 1989; cf. Shatz and Luskin, 1986). Primary auditory cortex is likely to be at a similar stage of development (see, e.g., Feng and Brugge, 1983; Myslivecek, 1983). Thus, in the rewired ferrets, we have replaced auditory input with visual input at a time when cortical circuits have not yet been fully established. It is likely that, at this stage in development, the microcircuitry of $\mathrm{Al}$ can be regulated significantly by afferent input, regardless of modality (see also Schlaggar and O'Leary, 1991). It is possible that similar lesions made at an earlier stage of development would produce an even more dramatic change in organization of the auditory pathway, such as changing the divergent nature of auditory thalamocortical connectivity to a point-to-point connectivity (cf. Pallas, 1990; Sur et al., 1990).

\section{Do sensory cortices share common processing circuits?}

An alternative interpretation of our data is that $\mathrm{Al}$ and $\mathrm{Vl}$ normally share at least ccrtain similar processing circuits, and that visual inputs to $\mathrm{Al}$ simply activate circuits normally present in A1. A1 thus comes to exhibit visual receptive field properties similar to those in normal V1. In this view, the common functional transformations that sensory cortices perform would include tuning for orientation and direction as well as generation of specific receptive field organization.

Anatomically, cortical laminae in $\mathrm{Al}$ and $\mathrm{Vl}$ are characterized by similar patterns of inputs, outputs, as well as laminar cell type composition (e.g., Jones, 1984; Winer, 1984a,b, 1985; Mitani and Shimokouchi, 1985); similar intralaminar projection patterns (e.g., Gilbert and Wiesel, 1979; Mitani et al., 1985); and the presence of patchy local horizontal connectivity patterns (Matsubara and Phillips, 1988; e.g., Gilbert and Wiesel, 1989b). Physiologically, perhaps akin to direction selectivity in V1, many neurons in Al respond selectively to the direction and rate of frequency modulation (Whitfield and Evans, 1965; Mendelson and Cynader, 1985). In addition, similar to cells in normal V1, the tuning of A1 cells is shaped importantly by intracortical inhibition. Analogous to findings in both the adult and developing visual cortex (Sillito, 1975; Fregnac et al., 1988; Greuel et al., 1988; Hata et al., 1988), local application of GABA antagonists such as bicuculline and excitatory agents such as ACh, norepinephrine, NMDA, and glutamate results in dramatic changes in receptive field tuning properties of cells in A1 (Müller and Scheich, 1988; Ashe et al., 1989; McKenna et al., 1989a; Metherate and Weinberger, 1989). In addition, the study of context-dependent responses in both visual (Gilbert and Wiesel, 1989a; Fox et al., 1990) and auditory cortices (Espinosa and Gerstein, 1988; McKenna et al., 1989b; Shamma et al., in press) supports the role of lateral inhibitory/modulatory mechanisms in shaping receptive field characteristics. These anatomical and functional parallels suggest that sensory cortices may indeed utilize some common processing mechanisms. Thus, the presence of orientation-selective cells in $\mathrm{Al}$ of rewired ferrets may suggest that similar "orientation tuning" transformations occur normally in Al.

If sensory cortices share some common processing circuits, these circuits can be established regardless of input modality during development. Consistent with this view, certain receptive field properties such as orientation tuning and simple/complex receptive field organization are already present in the young, visually inexperienced visual cortex (Hubel and Wiesel, 1963; Albus and Wolf, 1984; Braastad and Heggelund, 1985). The fact that "normal" visual receptive field properties are found in Al of rewired ferrets suggests that the development of many cortical receptive field properties is not dependent on cell class-specific $(\mathrm{X}, \mathrm{Y}$, or $\mathrm{W})$ patterns of sensory input, and develop, in fact, despite a relatively weak source of retinal input (of the $W$ type) and despite the different pattern of thalamocortical connectivity that characterizes the auditory pathway (Pallas et al., 1990). That is not to say that normal cortical circuits develop in the total absence of sensory input; a minimal amount of sensory input may be required to trigger events that result in establishment of these cortical circuits.

\section{Concluding remarks}

In conclusion, our results demonstrate that sensory neocortex is not uniquely specified to process inputs of a single modality. Auditory cortex, following specific lesions during development, can accept and process visual input. The visual transformations performed by auditory cortex appear very similar to those in normal visual cortex. Whether these functional similarities are 
due to input-induced changes in intracortical circuitry or to intrinsic commonalities across sensory cortices remains to be determined. A view consistent with that in other developing systems is that basic intracortical connections would be established independent of afferents, while input activity would play a role in the elaboration or fine-tuning of these connections. Such modulation by input activity would include alterations in the weights of preexisting synapses in the cortex (e.g., Merzenich et al., 1984; Donoghue and Sanes, 1988; Gilbert and Wiesel, 1989a; Mioche and Singer, 1989; Fox, 1990; Jenkins et al., 1990; Kaas et al., 1990). Indeed, our experiments on the mapping of the visual field in A1 of rewired animals (Roe et al., 1990a) indicate that one way for the map to form is by alterations in intracortical inhibition due to visual inputs (Sur et al., 1990).

\section{References}

Albus K, Wolf W (1984) Early post-natal development of neuronal function in the kitten's visual cortex: a laminar analysis. J Physiol (Lond) 348:153-185.

Andersen RA, Knight PL, Merzenich MM (1980) The thalamocortical and corticothalamic connections of AI, AII, and the anterior auditory field (AAF) in the cat: evidence for two largely segregated systems of connections. J Comp Neurol 194:663-701.

Ashe JH, McKenna TM, Weinberger NM (1989) Cholinergic modulation of frequency receptive fields in auditory cortex: II. Frequencyspecific effects of anticholinesterases provide evidence for a modulatory action of endogenous ACh. Synapse 4:44-54.

Bear MF, Kleinschmidt A, Gu Q, Singer W (1990) Disruption of experience-dependent synaptic modifications in striate cortex by infusion of an NMDA receptor antagonist. J Neurosci 10:909-925.

Blakemore C, Cooper GF (1970) Development of the brain depends on the visual environment. Nature 228:477-478.

Braastad BO, Heggelund P (1985) Development of spatial receptive field organization and orientation selectivity in kitten striate cortex. J Neurophysiol 53:1158-1178.

Chapman B, Jacobson MD, Reiter HO, Stryker MP (1986) Ocular dominance shift in kitten visual cortex caused by imbalance in retinal electrical activity. Nature 324:154-156.

Cleland BG, Levick WR (1974a) Brisk and sluggish concentrically organized ganglion cells in the cat's retina. J Physiol (Lond) 240:421456.

Cleland BG, Levick WR (1974b) Properties of rarely encountered types of ganglion cells in the cal's retina and an overall classification. J Physiol (Lond) 240:457-492.

Donoghue JP, Sanes JN (1988) Organization of adult motor cortex representation patterns following neonatal forelimb nerve injury in rats. J Neurosci 8:3221-3232.

Esguerra M, Garraghty PE, Russo GS, Sur M (1986) Lateral geniculate nucleus in normal and monocularly deprived ferrets: $\mathrm{X}$ - and $\mathrm{Y}$-cells and cell body size. Soc Neurosci Abstr 12:10.

Espinosa IE, Gerstein GL (1988) Cortical auditory neuron interactions during presentation of 3-tone sequences: effective connectivity. Brain Res 450:39-50.

Eysel UT, Worgotter F, Paper HC (1987) Local cortical lesions abolish lateral inhibition at direction selective cells in visual cortex. Exp Brain Res 68:606-612.

Felleman DJ, Van Essen DC (1987) Receptive field properties of neurons in area V 3 of macaque monkey extrastriate cortex. J Neurophysiol 57:889-920.

Feng JZ, Brugge JF (1983) Postnatal development of auditory callosal connections in the kitten. J Comp Neurol 214:416-426.

Ferster D (1990a) X-and Y-mediated synaptic potentials in neurons of areas 17 and 18 of cat visual cortex. Vis Neurosci 4:115-133.

Ferster D (1990b) X-and Y-mediated current sources in areas 17 and 18 of cat visual cortex. Vis Neurosci 4:135-145.

Fox JM, Delbruck T, Gallant JL, Anderson CH, Van Essen DC (1990) Modulation of classical receptive field responses by moving texture backgrounds in monkcy striatc cortcx: spatial and temporal interactions. Soc Neurosci Abstr 16:1270.

Fregnac Y, Shulz D, Thorpe S, Bienenstock E (1988) A cellular analogue of visual cortical plasticity. Nature 333:367-370.
Frost DO, Metin C (1985) Induction of functional retinal projections to the somatosensory system. Nature 317:162-164.

Fukuda Y, Hsiao CF, Watanabe M, Ito H (1984) Morphological correlates of physiologically identified $\mathrm{Y}_{-}, \mathrm{X}-$, and $\mathrm{W}$-cells in cat retina. J Neurophysiol 52:999-1013.

Gilbcrt CD (1977) Laminar differences in receptive field properties of cells in cat primary visual cortex. J Physiol (Lond) 268:391-421.

Gilbert CD, Wiesel TN (1979) Morphology and intracortical projections of functionally characterized neurones in the cat visual cortex. Nature 280:120-125.

Gilbert CD, Wiesel TN (1989a) The influence of contextual patterns on orientation selectivity in V1 of the cat. Soc Neurosci Abstr 15: 324.

Gilbert CD, Wiesel TN (1989b) Columnar specificity of intrinsic horizontal and corticocortical connections in cat visual cortex. J Neurosci 9:2432-2442.

Greucl M, Luhmann HJ, Singer W (1988) Pharmacological induction of use-dependent receptive field modifications in the visual cortex. Science 242:74-77.

Hata Y, Tsumoto T, Sato H, Hagihara K, and Tamura H (1988) Inhibition contributes to orientation selectivity in visual cortex of the cat. Nature 335:815-817.

Hubel DH, Wiesel TN (1962) Receptive fields, binocular interaction, and functional architecture in the cat's visual cortex. J Physiol (Lond) 160:106-154.

Hubel DH, Wiesel TN (1963) Receptive fields of cells in striate cortex of very young, visually inexperienced kittens. J Neurophysiol 26:9941002.

Imbert M, Buisseret P (1975) Receptive field characteristics and plastic properties of visual cortical cells in kittens reared with or without visual experience. Exp Brain Res 22:25-36.

Jackson CA, Peduzzi JD, Hickey TL (1989) Visual cortex development in the ferret. I. Genesis and migration of visual cortical neurons. J Neurosci 9:1242-1253.

Jenkins WM, Merzenich MM, Ochs MT, Allard T, Guic-Robles E (1990) Functional reorganization of primary somatosensory cortex in adult owl monkeys after behaviorally controlled tactile stimulation. J Neurophysiol 63:82-104.

Jones EG (1984) Identification and classification of intrinsic circuit elements in the neocortex. In: Dynamic aspects of neocortical function (Edelman G, Gall E, Cowan WM, eds), pp 7-40. New York: Wiley.

Kaas JH, Krubitzer LA, Chino YM, Langston AL, Polley EH, Blair N (1990) Reorganization of retinotopic cortical maps in adult mammals after lesions of the retina. Science 248:229-231.

Kasamatsu T, Pettigrew JD (1979) Preservation of binocularity after monocular deprivation in the striate cortex of kittens treated with 6-hydroxydopamine. J Comp Neurol 185:139-162.

Kelly JB, Judge PW, Phillips DP (1986) Representation of the cochlea in primary auditory cortex of the ferret (Mustela putorius). Hearing Res 24:111-115.

Law MI, Lahs KR, Stryker MP (1988) Organization of primary visual cortex (area 17) in the ferret. J Comp Neurol 278:157-180.

LeVay S, McConnell SK, Luskin MB (1987) Functional organization of primary visual cortex in the mink (Mustela vison), and a comparison with the cat. J Comp Neurol 257:422-441.

I eventhal AGr, Zhou Y, Ault SI, Thompson KG (1990) Cortical contribution to the orientation sensitivity of relay cells in the cat lateral geniculate nucleus. Soc Neurosci Abstr 16:176.

Malpeli JG, Schiller PH, Colby CL (1981) Response properties of single cells in monkey striate cortex during reversible inactivation of individual lateral geniculate laminae. J Neurophysiol 46:1102-1119.

Matsubara JA, Phillips DP (1988) Intracortical connections and their physiological correlates in the primary auditory cortex (A1) of the cat. J Comp Neurol 268:38-48.

McConnell SK (1988) Fates of visual cortical neurons in the ferret after isochronic and heterochronic transplantation. J Neurosci 8:945974.

McKenna TM, Ashe JH, Weinberger NM (1989a) Cholinergic modulation of frequency receptive fields in auditory cortex: I. Frequencyspecific effects of muscarinic agonists. Synapse 4:30-43.

McKenna TM, Weinberger NM, Diamond DM (1989b) Responses of single auditory cortical neurons to tone sequences. Brain Res 481: $142-153$.

Mendelson JR, Cynader MS (1985) Sensitivity of cat primary auditory cortex (A1) neurons to the direction and rate of frequency modulation. Brain Res 327:331-335. 
Merzenich MM, Jenkins WM, Middlebrooks JC (1984) Observations and hypotheses on special organizational features of the central auditory nervous system. In: Dynamic aspects of neocortical function (Edelman GM, Gall WE, Cowan WM, eds), pp 397-424. New York: Neurosciences Research Foundation.

Metherate R, Weinberger NM (1989) Acetylcholine produces stimulus-specific receptive field alterations in cat auditory cortex. Brain Res 480:372-377.

Metin C, Frost DO (1989) Visual responses of neurons in somatosensory cortex of hamsters with experimentally induced retinal projections to somatosensory thalamus. Proc Natl Acad Sci USA 86:357361 .

Middlebrooks JC, Zook JM (1983) Intrinsic organization of the cat's medial geniculate body identified by projections to binaural responsespecific bands in the primary auditory cortex. J Neurosci 3:203-224.

Mioche L, Singer W (1989) Chronic recordings from single sites of kitten striatc cortex during expcricnce-dependent modifications of receptive-field properties. J Neurophysiol 62:185-197.

Mitani A, Shimokouchi M (1985) Neuronal connections in the primary auditory cortex: an electrophysiological study in the cat. J Comp Neurol 235:417-429.

Mitani A, Shimokouchi M, Itoh K, Nomura S, Kudo M, Mizuno N (1985) Morphology and laminar organization of electrophysiologically identified neurons in the primary auditory cortex in the cat. $J$ Comp Neurol 235:430-447.

Movshon JA, Van Sluyters RC (1981) Visual neural development. Annu Rev Psychol 32:477-522.

Müller CM, Scheich H (1988) Contribution of GABAergic inhibition to the response characteristics of auditory units in the avian forebrain. J Neurophysiol 59:1673-1689.

Mullikin WH, Jones JP, Palmer LA (1984) Receptive field properties and laminar distribution of X-like and Y-like simple cells in cat area 17. J Neurophysiol 52:350-371.

Myslivecek J (1983) Development of the auditory evoked responses in the auditory cortex in mammals. In: Development of auditory and vestibular systems (Romand R, ed), pp 167-209. New York: Academic.

Orban GA, Kennedy H, Maes H (1981) Response to movement of neurons in areas 17 and 18 of the cat: velocity sensitivity. J Neurophysiol 45:1043-1058.

Pallas SL (1990) Cross-modal plasticity in sensory cortex. In: The neocortex: ontogeny and phylogeny (Finlay BL, Innocenti G, Scheich H, eds), pp 205-218. New York: Plenum.

Pallas SL, Roe AW, Sur M (1988) Retinal projections induced into auditory thalamus in ferrets: changes in inputs and outputs of primary auditory cortex. Soc Neurosci Abstr 14:460.

Pallas SL, Hahm JO, Sur M (1989) Retinal axon arbors in a novel target: morphology of ganglion cell axons induced to arborize in the medial geniculate nucleus of ferrets. Soc Neurosci Abstr 15:495.

Pallas SL, Roe AW, Sur M (1990) Visual projections induced into the auditory pathway of ferrets. I. Novcl inputs to primary auditory cortex (Al) from the LP/pulvinar complex and the topography of the MGNAl projection. J Comp Neurol 298:50-68.

Palmer LA, Davis TL (1981) Receptive field structure in cat striate cortex. J Neurophysiol 46:260-276.

Palmer LA, Rosenquist AC (1974) Visual receptive fields of single striate cortical units projecting to the superior colliculus in the cat. Brain Res 67:27-42.

Peduzzi JD (1988) Genesis of GABA-immunoreactive neurons in the ferret visual cortex. J Neurosci 8:920-931.

Pettigrew JD (1974) The effect of visual experience on the development of stimulus specificity by kitten cortical neurones. J Physiol 237:49_ 74.

Price DJ, Morgan JE (1987) Spatial properties of neurones in the lateral geniculate nucleus of the pigmented ferret. Exp Brain Rcs 68:28-36.

Redies C, Diksic M, Rimi H (1990) Functional organization in the ferret visual cortex: a double-label 2-deoxyglucose study. J Neurosci 10:2791-2803.

Reiter HO, Stryker MP (1988) Neural plasticity without action potentials: less active inputs become dominant when kitten visual cortical cells are pharmacologically inhibited. Proc Natl Acad Sci USA 85:3623-3627.

Roe AW (1991) Functional transformations of visual input by auditory thalamus and cortex: an experimentally induced visual pathway in ferrets. PhD thesis, MIT.

Roe AW, Garraghty PE, Sur M (1987) Retinotectal W-cell plasticity: experimentally induced retinal projections to auditory thalamus in ferrets. Soc Neurosci Abstr 13:1023.

Roe AW, Garraghty PE, Sur M (1989) The terminal arbors of single on-center and off-center $X$ and $Y$ retinogeniculate axons within the ferret's lateral geniculate nucleus. J Comp Neurol 288:208-242.

Roe AW, Pallas SL, Hahm JO, Sur M (1990a) A map of visual space induced into primary auditory cortex. Science 250:818-820.

Roe AW, Pallas SL, Kwon YH, Sur M (1990b) Visually innervated auditory cortex in ferrets generates visual response properties similar to those in normal visual cortex. Soc Neurosci Abstr 16:984.

Schiller PH, Finlay BL, Volman SF (1976a) Quantitative studies of single-cell properties in monkey striate cortex. I. Spatiotemporal organization of receptive fields. J Neurophysiol 39:1288-1319.

Schiller PH, Finlay BL, Volman SF (1976b) Quantitative studies of single-cell properties in monkey striate cortex. II. Orientation specificity and ocular dominance. J Neurophysiol 39:1320-1333.

Schlaggar BL, O'Leary DDM (1991) Potential of visual cortex to develop an array of functional units unique to somatosensory cortex. Science 252:1556-1560.

Schneider GE (1973) Early lesions of superior colliculus: factors affecting the formation of abnormal retinal projections. Brain Behav Evol 8:73-109.

Shamma SA, Fleshman JW, Wiser PR (1992) Receptive field organization in ferret primary auditory cortex: spectral orientation columns. J Neurophysiol, in press.

Shatz CJ, Luskin MB (1986) The relationship between the geniculocortical afferents and their cortical target cells during development of the cat's primary visual cortex. J Neurosci 6:3655-3668.

Sherman SM, Spear PD (1982) Organization of visual pathways in normal and visually deprived cats. Physiol Rev 62:738-855.

Sillito AM (1975) The contribution of inhibitory mechanisms to the receptive field properties of neurons in the striate cortex of the cat. J Physiol (Lond) 250:305-322.

Stanford LR (1987) W-cells in the cat retina: correlated morphological and physiological evidence for two distinct classes. J Neurophysiol 57:218-244

Stryker MP, Harris WA (1986) Binocular impulse blockade prevents the formation of ocular dominance columns in cat visual cortex. $J$ Neurosci 6:2117-2133.

Sur M, Sherman SM (1982) Linear and nonlinear W-cells in C-laminae of the cat's lateral geniculate nucleus. J Neurophysiol 47:869-884.

Sur M, Garraghty PE, Roe AW (1988) Experimentally induced projections into auditory thalamus and cortex. Science 242:1437-1441.

Sur M, Pallas SL, Roe AW (1990) Cross-modal plasticity in cortical development: differentiation and specification of sensory neocortex. Trends Neurosci 13:227-233.

Tanaka K (1983) Cross-correlation analysis of geniculostriate neuronal relationships in cats. J Neurophysiol 49:1303-1318.

Vitek DJ, Schall JD, Leventhal AG (1985) Morphology, central projections, and dendritic field orientation of retinal ganglion cells in the ferret. J Comp Neurol 241:1-11.

Whitfield IC, Evans EF (1965) Responses of auditory cortical neurons to stimuli of changing frequency. J Neurophysiol 28:655-672.

Wiesel TN, Hubel DH (1965) Comparison of the effects of unilateral and bilateral eye closure on cortical unit responses in kittens. J Neurophysiol 28:1029-1040.

Wilson PD, Rowe MH, Stone J (1976) Properties of relay cells in the cat's lateral geniculate nucleus: a comparison of $\mathrm{W}$-cells with $\mathrm{X}$ - and Y-cells. J Neurophysiol 39:1193-1209.

Winer JA (1984a) Anatomy of layer IV in cat primary auditory cortex (A1). J Comp Neurol 224:535-567.

Winer JA (1984b) The non-pyramidal cells in layer III of cat primary auditory cortex (A1). J Comp Neurol 229:512-530.

Winer JA (1985) Structure of layer II in cat primary auditory cortex (A1). J Comp Neurol 238:10-37.

Zahs KR, Stryker MP (1985) The projection of the visual field onto the lateral geniculate nucleus of the ferret. J Comp Neurol 241:210 224.

Zahs KR, Stryker MP (1988) Segregation of ON and OFF afferents to ferret visual cortex. J Neurophysiol 59:1410-1429. 